\title{
Corporate Responsibility and Corporate Governance in Europe
}

\author{
Luca Bisio
}

\begin{abstract}
The policies adopted by multinationals have generated some rather harsh criticism due to the insensitivity shown with regard to the environment, food safety and social marginalisation. This is due to the fact that excess supply conditions, which now characterize the richer markets, have forced companies into a 'neo-liberalism' spiral.

The strong dynamism exhibited by corporations in taking advantage of the opportunities offered by globalisation, contrast with the inadequacy of institutions (and, in particular, of Nation-States). Basically, it becomes more and more difficult for Nation-States to build bridges between the global system and local socioeconomic systems.
\end{abstract}

Keywords: Corporate Responsibility; Corporate Social Responsibility; Global Market; Effects of Globalisation; Local Governments; Global Cities

\section{The Relationship Between Corporate Governance and Corporate Responsibility}

The origins of corporate governance (Figure 1) can be traced to problems resulting from the growing number of stock exchange listings, throughout the world, by companies with dispersed ownership. The separation between capitalproviding shareholders and company management (directors and senior management) has effectively posed new significant questions regarding the need for balanced safeguards for the not necessarily convergent interests of the parties involved.

From its beginnings in the late 80's and with the added impetus of the 90's, the debate on corporate governance has developed enormously as a consequence of new dynamic conditions within the economic system (both globally and locally) and in corporate behaviour. In addition, there is a growing conviction that competitiveness and accountability are increasingly linked to the concept of corporate governance ${ }^{1}$. In 1999, this led the OECD to produce the first draft and

* Lecturer in Management, University of Milan-Bicocca (luca.bisio@unimib.it)

Edited by: ISTEI - University of Milan-Bicocca

ISSN: 1593-0319

Bisio Luca, Corporate Responsibility and Corporate Governance in Europe, Symphonya. Emerging Issues in Management (symphonya.unimib.it), n. 1, 2003, pp. 99-113

http://dx.doi.org/10.4468/2003.1.09bisio 
subsequent revisions of the principles of corporate governance ${ }^{2}-$ duly approved by member country Ministries.

Figure 1: A Comparison of Corporate Governance Definitions

\begin{tabular}{|l|l|}
\cline { 2 - 2 } \multicolumn{1}{c|}{ Source } & \multicolumn{1}{|c|}{ Definition } \\
\hline Cadbury code (UK) & $\begin{array}{l}\text { A system whereby companies are managed and } \\
\text { controlled. }\end{array}$ \\
\hline OECD principles & $\begin{array}{l}\text { A set of rules governing the relationship between } \\
\text { company management, the board of directors, } \\
\text { shareholders and other stakeholders. }\end{array}$ \\
\hline $\begin{array}{l}\text { CalPERS governance } \\
\text { principles (US) }\end{array}$ & $\begin{array}{l}\text { Relationships between the various stakeholders in } \\
\text { deciding the general direction and performance of a } \\
\text { company. }\end{array}$ \\
\hline $\begin{array}{l}\text { Code of best practice for } \\
\text { corporate governance } \\
\text { (Germany) }\end{array}$ & $\begin{array}{l}\text { Set of tools for ensuring responsibility and orientation } \\
\text { towards value creation by those who manage and } \\
\text { control a company. }\end{array}$ \\
\hline Vienot report (France) & $\begin{array}{l}\text { A system that renders a company aware of, and } \\
\text { oriented towards, the pursuit of a country's common } \\
\text { interests. }\end{array}$ \\
\hline Preda Code (Italy) & $\begin{array}{l}\text { A set of rules whereby a company is managed and } \\
\text { controlled. }\end{array}$ \\
\hline
\end{tabular}

Source: Golinelli G.M., Vagnani G., Corporate Governance as a Viable System: the Role of Intra- and Inter-Systemic Relationships, Symphonya. Emerging Issues in Management (symphonya.unimib.it), $\mathrm{n}$. $2,2002$.

The aims of the principles are to:

- help governments in OECD member and non-member countries to analyse and improve their judicial, institutional and legislative framework on the subject of corporate governance;

- prepare structural papers and proposals to stock exchange authorities, investors, companies and other stakeholders through participation in the development of an effective corporate governance regime.

The principles are characterized by the fact that they:

- are not mandatory in content, but rather serve as road maps for legislators, governments and corporations on the subject of corporate governance;

- allow for individual application by the various member countries to take into account the different judicial, economic and cultural contexts ${ }^{3}$.

In dealing with the issue of the separation between ownership and control, the OECD principles do not concentrate solely on defining the relationship between shareholders and management. They instead go into greater depth on the issue of the relationship between the controlling interest in a company and minority shareholders, as well as the role of the other significant stakeholders in a company. In the governance of this set of relationships, particular emphasis is placed on the 
need for the timely publication of accurate information on financials, results, ownership and governance itself.

Respect for these guidelines is obviously important if we consider that corporate governance is one of the main factors in the improvement of effectiveness, economic growth and investor confidence. This is particularly significant for a company's potential access to global funding. If companies want to have access to the largest possible pool of investors - attracting capital by traditional means over the long term - they will have to equip themselves with believable corporate governance systems that can be understood equally well abroad and be based on a minimum of accepted principles.

Given these premises, it is important, however, to add that corporate governance is only one element in the general economic context in which a company conducts business. Other factors, specifically business ethics and corporate conscience, reflect the environmental and social concerns that prevail within a company's community and can equally well affect the reputation and success of a company over the long term.

\section{Changed Outlook Due to Market Globalisation}

OECD concerns regarding the necessity not to limit attention solely to the issue of corporate governance, can be traced to market globalisation. Markets have long been considered to be one of the pillars of civilization. It was the market that originally supplanted violence, robbery and theft, thereby establishing relationships based on communication, reasoning, interests and the acceptance of diversity. In addition, by placing the various players within the economy in competition with one another, markets have generated other markets through emulation, and brought about nothing less than a race towards material progress. A spirit of enterprise has joined with markets and competition to together initiate economic development and technical creativity.

However, with the advent of globalisation, it has become important to ask ourselves whether the competitive dynamic, as a factor of progress, has to still be left as unencumbered as possible on a global scale in order to ensure the maximum well-being of humanity ${ }^{4}$. If we are to attempt to contribute to answering this complex question, we first have to focus on two themes:

- the first effects of the globalisation process;

- the balance of power between companies and nation-states.

\subsection{The Effects of Globalisation}

The policies adopted by multinationals have generated some rather harsh criticism due to the insensitivity shown with regard to the environment, food safety and social marginalisation. This is due to the fact that excess supply conditions, which now characterize the richer markets, have forced companies into a 'neo-liberalism' spiral. This means an exasperated search for product market outlet, effected at minimal production and marketing cost by means of exploitation - sometimes intensive, 
irrational and in some cases socially uneconomical - of the fundamental production factors (capital, labour and natural resources) ${ }^{5}$.

Furthermore, the rate of technological and economic change imposed by globalisation has often been more rapid than that of political, civil and institutional society. Administrative, social and educational systems have proven unable to keep pace with this evolutionary process and the gap has had serious effects on such problems as inequality, exclusion, dissociation and social breakdown.

These claims are demonstrable by the analysis of some of the specific effects of globalisation. First, in this changed context, economic and social relations are more than ever linked to a complex set of functions: knowledge, information, cultural harmony, adaptability to diversity, action/reaction time, mobility, etc.

Such functions go beyond the sphere of association with a physical place (geographical area, country, ethnic group, etc.) arranged to safeguard specific exclusive local rights and duties. Company policies based on an 'enlarged' competitive space (market space management) specifically envisage the overcoming of the usual direct control and proximity limits, and the establishment of operating environments marked by the need for constant competitive adaptability and management flexibility ${ }^{6}$.

This affects, amongst other things:

- $\quad$ production processes $\rightarrow$ that are not necessarily fixed permanently at a given place, with obvious consequences for the local labour market ${ }^{7}$;

- the dichotomy between production and procurement locations where sales/distribution are located. $\rightarrow$ In view of the attenuation of territorial bonds, this allows companies to take advantage of the differences between countries, thus benefiting from the most favourable corporate conditions at any point in time. Best conditions are at times achieved at the expense of safeguards for workers and where the rules for environment protection may be particularly permissive, etc.).

Second, it is clear that the orientation towards technological progress is being carried forward increasingly by private individuals, hence bypassing the public authorities' sphere of influence. It is companies that often decide what type of research they will engage in and, as a consequence, what goods and services they will sell. This choice is obviously influenced by the market, with negative effects as regards both 'commercial' and 'non-commercial' goods and services. With respect to the former, we can take, for example, pharmaceutical research. Given that there is product demand by 'solvent' consumers, companies focus on the development, production and sale of products for the treatment of pathologies typically found in rich countries (such as obesity, impotence, tumours, etc.) and almost completely neglect efforts that should be made to treat the typical needs of people who populate the rest of the planet.

The multinationals' invasion of 'non-commercial' products poses an ethical problem at least as serious as the first one. We can see, for example, how the growing influence of large multimedia groups on education and culture has given them what almost amounts to a monopoly on themes that were previously public in nature. Over a period of time, there has been a gradual expansion of their sphere of influence from pure amusement and entertainment to what they believe to be 
'educational' (edutainment). Alongside this dangerous 'role acquisition' is the fact that multimedia and telecommunications companies have a planetary impact. They are spreading uniform cultural and educational models worldwide, thereby contributing to the weakening of local cultures ${ }^{8}$.

\subsection{The Strength of Companies}

We have shown how companies (and the investment funds that control them) are the most dynamic elements within the globalisation process, capable of enormous influence. Indeed, they have been amongst the few organisations capable of crossing all the thresholds of globalisation simultaneously, specifically the thresholds of:

- $\quad$ size $\rightarrow$ they are international and unaffected by state and national borders;

- time horizon $\rightarrow$ they apply long-term strategies, using measures that are not comparable to those of the political, administrative or educational worlds;

- complexity $\rightarrow$ they are capable of efficiently managing differences, multiple rationales, risk, resource development, and of adapting rapidly to continuous environmental changes;

- information and communications $\rightarrow$ they are linked directly to the whole world and act promptly and efficiently ${ }^{9}$.

In addition to the above, they have at their disposal market information that is so extensive and sophisticated that they often find themselves competing with governments in establishing guidelines for local development ${ }^{10}$.

\subsection{The Weakness of Nation-States}

Business has adapted to globalisation much more quickly than political, social and educational institutions. The world economy was 'settled' by companies and financial brokers before the new rules of the expanded economic game could be fully established. In this type of situation, private enterprises use their own decision criteria that are, of course, economic, commercial and financial. These criteria are essential for a company's strategic effectiveness but do not cover the entire area of the common good. Hence companies impose, often without even so much as a political debate, the new rhythm of change, the orientation of economic and technological progress and their presence in non-commercial domains.

The strong dynamism exhibited by corporations in taking advantage of the opportunities offered by globalisation, contrast with the inadequacy of institutions (and, in particular, of nation-states ${ }^{11}$ ). Institutional authority is insufficient to control global flows and internal organisation is generally too rigid to adapt to constant change within the world system. The many territorial identities that aspire to be represented by nation-states generate ever-increasing conflicting processes that, in the final analysis, tend to delegitimise the very idea of national representation. Basically, it becomes more and more difficult for nation-states to build bridges between the global system and local socio-economic systems. The latter are therefore induced to seek more immediate points of reference within local and regional governments. These entities are proving to be institutionally more flexible, closer to their own cultural identity and therefore better suited to 
successfully negotiate the continuous adaptation to change imposed globally, while defending and recognising the value of the synergies and competitive advantages that exist at the local level. However, the gradual strengthening of local government powers is not without limits and risks, such as:

- administrative dependency on central governments;

- even more limited capabilities in terms of economic resources;

- the risk of sliding towards political localism and cultural tribalism that can lead to closed local socio-economic systems with the consequent loss of competitiveness for the companies that operate there ${ }^{12}$.

It is for these reasons that the globalisation process imposes a risk on states, without even leaving them a choice in the type of market economy that is best for their country. This is why the Anglo-Saxon model (more financial and less social) is gaining ground every day, to the detriment of a 'social' economic view of the market (Rhine model $)^{13}$. As a result of its strength and international dynamism, the market economy tends to operate in its own interests, without taking sufficiently into account the social, cultural or political consequences of a system driven by financial and commercial criteria. One of the risks is in erecting a finely tuned market and competition mechanism, while forgetting that these are only a means to an end, at the service of developing society as a whole ${ }^{14}$.

World production is now 50 times as great as it was in 1820 while the population is only 6 times as numerous. The division of this prosperity, however, is more unequal than ever. The basic problem is that we find ourselves having to deal with changes that are too rapid for our society to adapt to without excessive pain. One of the greatest challenges of our time is therefore to try and temper the dynamism of the market economy with social justice.

\section{Global Markets and Corporate Responsibility}

Globalisation, as we have seen, has caused inevitable fractures between transnational corporations, local governments and the organisations that control international competition (antitrust commissions, central banks, etc.), and caused social tension on a vast scale. However, it remains an 'open' process, capable of producing different outcomes depending on how the organisations involved are able to manage it. Amongst other things, two concepts that have to be taken into consideration in any attempt to direct the impulse for change in the right direction are:

- the 'common good' of the planet should be expressed in a democratic and political manner, and not only from the economic viewpoint ${ }^{15}$, thereby redefining the role of nation-states and global cities ${ }^{16}$;

- the social tensions caused by globalisation have to be settled through a modern approach to corporate social responsibility ${ }^{17}$ (CSR) that is capable of going beyond - through integration - the traditional definition of corporate governance $^{18}$.

We will now try to expand on these concepts to provide a contribution to the discussion on the theme of globalisation. 


\subsection{Local Governments and Global Cities}

In order to do better than a merely economic approach to the 'common good', government practices would have to change in broad concrete ways. As things now stand:

- the concept of government as an organisation devoted exclusively to public affairs within a country seems more and more inadequate ${ }^{19}$;

- globalisation is taking us to a level of interdependence such that the balance of powers policies will be gradually replaced by the collective practice of government on a world scale ${ }^{20}$.

All the skills and strategic ability of business are needed to attempt to add to effective competitive mechanisms servicing 'solvent' markets, cooperative actions to service the world's urgent causes (water, health, pollution, etc. ${ }^{21}$. It is obvious that dealing with transnational corporations operating through global strategies can only be carried out by governments that operate using transversal, shared and synergistic logic. If this reasoning is true for nation-states, the same concepts also have to apply to the global cities that constitute nodes in the global economic network. Therefore, we must prepare our cities to deal with competition by focusing on three development factors:

- connection $\rightarrow$ by connecting cities into communications, telecommunications and information networks on a regional, national and global scale;

- innovation $\rightarrow$ through generating knowledge of economic activities based on the potential to obtain and process strategic information;

- institutional flexibility $\rightarrow$ consisting of internal skills and external independence in negotiating distribution development with both corporations and institutions that operate at the trans local level ${ }^{22}$.

Under the 'coordinated' cooperation framework, corporations would not only play the role of businessman and manager. They would become part of a general interest forum that is not only mercantile in nature, and would accept the concept of expanded corporate responsibility in pursuit of the common good - with a subsequent increase in corporate legitimacy.

In encouraging this view, the Secretary general of the U.N. launched the Global Compact. The intention was to create a partnership between the U.N., multinational corporations, the ILO (International Labour Organization), nongovernment organisations and Amnesty International ${ }^{23}$. The Compact was announced at the World Economic Forum in Davos in January 1999 and formally presented to the U.N. in July 2000. It is a voluntary initiative that attempts to provide a global framework for the promotion of sustainable development and a sense of citizenship through committed, creative corporate leadership ${ }^{24}$. The Global Compact asks companies to embrace, support and enact, within their sphere of influence, a set of core values in the areas of human rights, labour standards and the environment, expressed through their respect for nine universal principles (Figure 2), with the explicit goal of:

- promoting shared values and principles;

- building a more inclusive and fairer global market;

- using their know-how to eradicate poverty and inequality ${ }^{25}$. 
Figure 2: The Nine Principles of the Global Compact

\begin{tabular}{|c|c|}
\hline Spheres & Principles \\
\hline \multirow[t]{2}{*}{ Human Rights } & $\begin{array}{l}\text { 1. Businesses should support and respect the } \\
\text { protection of internationally proclaimed human rights; } \\
\text { and }\end{array}$ \\
\hline & $\begin{array}{l}\text { 2. make sure that they are not complicit in human } \\
\text { rights abuses. }\end{array}$ \\
\hline \multirow[t]{4}{*}{ Labour Standards } & $\begin{array}{l}\text { 3. Businesses should uphold the freedom of } \\
\text { association and the effective recognition of the right to } \\
\text { collective bargaining; }\end{array}$ \\
\hline & $\begin{array}{l}\text { 4. the elimination of all forms of forced and } \\
\text { compulsory labour; }\end{array}$ \\
\hline & 5. the effective abolition of child labour; and \\
\hline & $\begin{array}{l}\text { 6. the elimination of discrimination in respect of } \\
\text { employment and occupation. }\end{array}$ \\
\hline \multirow[t]{3}{*}{ Environment } & $\begin{array}{l}\text { 7. Businesses should support a precautionary approach } \\
\text { to environmental challenges; }\end{array}$ \\
\hline & $\begin{array}{l}\text { 8. undertake initiatives to promote greater } \\
\text { environmental responsibility; and }\end{array}$ \\
\hline & $\begin{array}{l}\text { 9. encourage the development and diffusion of } \\
\text { environmentally friendly technologies. }\end{array}$ \\
\hline
\end{tabular}

\subsection{The Development of Corporate Social Responsibility}

Before concentrating on potential CSR development alternatives, it is important for us to avoid the risk of a superficial approach to the issue. We must remember that, 'a corporation is an economic, social and political institution, one that is characterized by the predominance of its economic function. [...] Its immediate aim is to satisfy institutional economic interest, that is, in a community of economic interests, pertaining to different persons, and in the continuity of business, a corporation achieves the common good. The common good derives from the unity of the means of satisfaction of different interests $\rightarrow$ the operation of a company within the institution. The institutional interests are the immediate goal of a company. Its non-institutional interests are conditions of a company's business activities, in the broader sense, these are limits or aims that are not immediate in the economic activity of the institution ${ }^{26}$.

Social responsibility is the inclusion by the company, on a voluntary basis, of social and environmental concerns in its commercial transactions and in its relations with stakeholders - according to the definition contained in the European Commission Green Paper. More than an aim in itself, it is an essential condition for the pursuit of the common good by the parties that comprise it. In short, the organisation and processes of corporate governance must in any case be guided by the two basic principles of economic viability and satisfaction of interests. On the basis of the economics principle, every company should be able to survive over time by pursuing its aims under conditions of economic independence. It is also necessary to ensure the principle of satisfaction of interests, which is achieved by adopting organisational structure and products, but above all attitudes and behaviours based on participation and comparison ${ }^{27}$.

Based on these premises, the importance of the development of corporate responsibility in social terms has already been stressed through the Global Compact in which the United Nations affirms the principle of presupposed nonconflict with 
corporations. On the contrary, it encourages active collaboration with a view to making them an integral part of the fight against poverty and inequality. Interest in this aspect is also reflected by the European Commission in its Green Book, 'promoting a European framework for corporate social responsibility'. The Commission defines CSR as 'the inclusion, on a voluntary basis, of social and environmental concerns by corporations in their commercial activities and in their relations with other parties ${ }^{28 ،}$. It identifies CSR as the fundamental element for the creation of a positive contribution to the:

- achievement of the strategic objective defined in March 2000 by the European Council in Lisbon: 'to become the economy with the most competitive and dynamic knowledge in the world, capable of sustainable growth accompanied by quantitative and qualitative improvements in employment and greater social cohesion, ${ }^{29}$;

- search for consistency with the fundamental message for a strategy of sustainable development adopted by the European Council of Göteborg in 2001: 'over the long term, economic growth, social cohesion and environmental safeguards proceed at the same rate'.

In specifying the reasons with greater short-term operational impact, the commission also explains that corporations, politicians and other stakeholders consider CSR a new form of governance that can help them to react to the following major transformations:

- new global responsibilities for companies, particularly with regard to developing countries;

- the importance of image and 'reputation' to a company's competitiveness as consumers and NGOs for their part, demand more and more detailed information with regard to the conditions under which goods and services are produced and their effects on sustainable development, and the trend to 'rewarding' companies which adopt socially or environmentally responsible practices;

- financial stakeholders' demands for more information than the traditional statements, in order to assess a company's intrinsic risk and success factors and the degree to which they take public opinion into account.

It is clear that the power of public opinion is essential to encourage companies to take further cognisance of their social responsibilities and create organisations that enable them to ensure the inclusion of environmental and social concerns in their business activities. In this context, many EU members have recognized the central function of CSR and have adopted active measures to promote it. For example in:

- Denmark, the Ministry for Social Affairs launched a 1994 campaign entitled 'A common concern: corporate social responsibility' and created the Copenhagen Centre in 1998;

- the United Kingdom, a Ministry for corporate social responsibility was created in March 2000. An inter-ministerial group was also created in order to ensure better coordination of activities designed to promote CSR in government circles. 
The Commission, in its Green Paper, also helped corporations to understand the various dimensions of CSR by identifying:

- an internal dimension: with reference to employees, shareholders and responsible environmental practices, with regard to the management of the natural resources used in production (Figure 3).

Figure 3: Corporate Social Responsibility: the Internal Dimension

\begin{tabular}{|c|c|c|}
\hline & CSR Target & CSR Actions \\
\hline \multirow{4}{*}{$\begin{array}{c}\text { Internal } \\
\text { Dimension }\end{array}$} & $\begin{array}{l}\text { Management of } \\
\text { human resources }\end{array}$ & $\begin{array}{l}\text { - } \text { Continuous training } \\
\text { - Employee empowerment } \\
\text { - Improving information flows in the company } \\
\text { - Improving the life-work balance } \\
\text { - Greater diversity in recruitment } \\
\text { - Non-discriminatory recruitment practices } \\
\text { - Application of the principle of equal remuneration and } \\
\text { - } \quad \text { Pareer prospects for women }\end{array}$ \\
\hline & $\begin{array}{l}\text { Health and safety } \\
\text { on the job }\end{array}$ & $\begin{array}{l}\text { - A culture of prevention } \\
\text { - Measures, documentation and external communication of } \\
\text { actions on the subject of health and safety on the job } \\
\text { - Safeguards for health and safety on the job as a criterion for } \\
\text { the selection of goods and services to purchase } \\
\text { - Safeguards for health and safety on the job as an aspect of } \\
\text { marketing for the sale of goods and services }\end{array}$ \\
\hline & $\begin{array}{l}\text { Adaptation to } \\
\text { change } \\
\text { (in the company) }\end{array}$ & $\begin{array}{l}\text { - Restructuring takes into consideration and balances the } \\
\text { interests and concerns of all the parties involved in changes } \\
\text { and decisions } \\
\text { - Ensuring participation and involvement of interested parties } \\
\text { through an open information and consultation procedure } \\
\text { - Analysis of alternative solutions with a view to minimizing } \\
\text { dismissals } \\
\text { - Investing in professional re-skilling } \\
\text { - Direct commitment by corporations for proactive labour } \\
\text { market policies through public partnerships in favour of } \\
\text { local employment and social integration }\end{array}$ \\
\hline & $\begin{array}{l}\text { Management of } \\
\text { the effects on the } \\
\text { environment and } \\
\text { natural resources }\end{array}$ & $\begin{array}{l}\text { - } \text { Reduction in the consumption of resources } \\
\text { - Reduction in the emission of pollutants and waste } \\
\text { - }\end{array}$ \\
\hline
\end{tabular}

Source: European Commission, Green Paper: Promoting an European Framework for Corporate Social Responsibility, Brussels, 2001.

- an external dimension: involving local communities in addition to a wide range of interested parties - commercial partners, suppliers, customers, public authorities, non-government organisations, etc. (Figure 4). 
Figure 4: Corporate Social Responsibility: the External Dimension

\begin{tabular}{|c|c|c|}
\hline & CSR Target & CSR Actions \\
\hline \multirow{4}{*}{$\begin{array}{c}\text { External } \\
\text { Dimension }\end{array}$} & Local communities & $\begin{array}{l}\text { - Job creation } \\
\text { - Childcare facilities for employees' children } \\
\text { - No tax evasion or avoidance } \\
\text { - Actions to reduce noise and the pollution of } \\
\text { water, air and soil } \\
\text { - Development of local policies for environmental } \\
\text { - } \text { - Sucation } \\
\text { - Support of local non-profit associations } \\
\text { - Donations }\end{array}$ \\
\hline & $\begin{array}{l}\text { Commercial partnerships, } \\
\text { suppliers and consumers }\end{array}$ & $\begin{array}{l}\text { - Commercial partnerships designed to simplify } \\
\text { production processes and thus reduce costs and } \\
\text { increase quality } \\
\text { - Extension of CSR conditions to all the } \\
\text { companies making up the production chain } \\
\text { - Support for local small business startups through } \\
\text { venture capital } \\
\text { - Support for extension of CSR action to local } \\
\text { small businesses } \\
\text { - Investment in understanding customer } \\
\text { expectations so as to target the level of quality } \\
\text { required } \\
\text { Production of products which can be used by the } \\
\text { greatest possible number of people (including } \\
\text { thedisabled) }\end{array}$ \\
\hline & Human rights & $\begin{array}{l}\text { - Codes of conduct on the subject of working } \\
\text { conditions and human rights, with particular } \\
\text { reference to subcontractors and suppliers } \\
\text { - The fight against corruption } \\
\text { - Initiatives aimed at poverty reduction and } \\
\text { increasing levels of education }\end{array}$ \\
\hline & $\begin{array}{l}\text { Global environmental } \\
\text { concerns }\end{array}$ & $\begin{array}{l}\text { - Improvements in environmental performance } \\
\text { along the entire production chain } \\
\text { - Investment aimed at sustainable growth }\end{array}$ \\
\hline
\end{tabular}

Source: European Commission, Green Paper: Promoting an European Framework for Corporate Social Responsibility, Brussels, 2001.

However, in a system characterized by multinational investments and global production chains, corporate social responsibility has to go beyond European Union borders and the actions of individual governments. In defining the strategies for promoting CSR (Figure 5), the Commission itself cites the need for it to:

- ensure full support for existing international agreements and instruments on the subject of CSR (fundamental ILO labour regulations, the main OECD directives to multinational corporations, etc.) and respect their decisions;

- take particular consideration of developing countries. 
Figure 5: Strategies for the Promotion of Corporate Social Responsibility

\begin{tabular}{|ll|}
\hline \multicolumn{1}{|c|}{ Principles } \\
\hline$\bullet$ & Recognition of the voluntary nature of CSR. \\
\hline - & Need to render socially responsible practices credible and transparent. \\
\hline - & Focus on activities in which community intervention provides added value. \\
\hline - & Balanced and global approach for CSR, including economic, social and environmental aspects, \\
& as well as the interests of consumers. \\
\hline - & Attention to the needs and characteristics of small and medium enterprises. \\
\hline - & Support for existing international agreements and instruments (fundamental ILO labour \\
& $\begin{array}{l}\text { regulations, the main OECD directives as they apply to multinational corporations) and respect } \\
\text { their decisions. }\end{array}$ \\
\hline & \multicolumn{1}{c|}{ Actions } \\
\hline - & $\begin{array}{l}\text { Provide more information about the positive effects of social responsibility on businesses and on } \\
\text { society, with particular reference to developing countries. }\end{array}$ \\
\hline$\bullet$ & $\begin{array}{l}\text { Bolster the corporate sharing of experiences and good practice on social responsibility with other } \\
\text { companies. }\end{array}$ \\
\hline$\bullet$ & Promote the development of CSR management skills. \\
\hline$\bullet$ & Encourage social responsibility amongst small and medium enterprises. \\
\hline$\bullet$ & Facilitate the convergence and transparency of CSR practices and instruments. \\
\hline$\bullet$ & Organize an 'EU Multi-Stakeholder Forum on CSR' \\
\hline$\bullet$ & Integrate CSR into EU polizie \\
\hline
\end{tabular}

On the basis of these premises, attempting to balance the power ratio between global market pressures and corporate responsibility would entail the following:

- overcome the view whereby corporations are the centre about which all other institutions revolve. See them instead as one of the elements in a system in which all the elements have to be 'responsible', in economic, social, environmental and ethical terms;

- corporations should start to listen to society, and not just to markets, thereby ensuring more responsible global action with regard to the entire chain of production and distribution;

- european governments should stop reasoning only as members of the EU and also see themselves as part of a global government;

- other stakeholders - in particular employees, consumers and investors should perform a decisive role in areas such as working conditions, the environment and human rights. They should invite corporations to adopt socially responsible practices, while leaving the decision to invest in CSR directions with companies. However, it must be stressed that there are risks associated with an interpretation of CSR that overlooks the essential aims of business, to which reference was made at the beginning of this section, or that do not consider its more critical elements.

In particular:

- we should not err by interpreting CSR improperly by confusing it with philanthropy, charity or patronage. Corporate social responsibility does not end with (and, indeed, is not even necessarily related to) the allocation of some company resources to causes of social relevance; 
- it must be noted - as even the EU admits - that there is still not enough objective data and information on the link between social responsibility and the financial performance of corporations;

- recognition and acceptance by the majority of consumers and investors should not be taken for granted when it comes to socially responsible behaviour, particularly if it reflects in significant ways on the purchase price for goods and services or on the potential return on capital invested.

\section{Bibliography}

Airoldi G., Brunetti G., Coda V., Economia aziendale, Il Mulino, Bologna, 1994.

Annan K., The Global Compact. Corporate Leadership in the World Economy, Symphonya. Emerging Issues in Management (symphonya.unimib.it), n. 2, 2002. http://dx.doi.org/10.4468/2002.2.02annan

Borja J., Castells M., La città globale. Sviluppo e contraddizioni delle metropoli del terzo millennio, De Agostini, Novara, 2002.

Brotchie J., Cities in Competition: Productive and Sustainable Cities for the Twenty-First Century, Sydney Longman Australia, 1995.

Brondoni S.M., Ouverture de 'Market-Space Management', Symphonya. Emerging Issues in Management (symphonya.unimib.it), n. 1, 2002. http://dx.doi.org/10.4468/2001.2.01ouverture

European Commission, Memorandum from the Commission to the Council, European Parliament and Economic and Social Committee. Promotion of fundamental labour standards and improvements in social governance within the framework of globalisation, Brussels, 2001.

European Commission, European Governance: a White Paper, Brussels, 2001.

European Commission, Green Paper: Promoting a European Framework for Corporate Social Responsibility, Brussels., 2001.

European Commission, Memorandum from the Commission in relation to corporate social responsibility: a contribution by business to sustainable development, Brussels, 2002.

De Montbrial Th., Le monde au tournant du siècle, Ramsès 2000, Paris, Dunod, 2000.

De Schoutheete Ph., Exposé fait au Colloqui Yalta, Europe in the 21st Century, 8 May 2000.

de Woot P., The Challenges of Economic Globalisation: Business, Competition and Society, Symphonya. Emerging Issues in Management (symphonya.unimib.it), n. 2, 2002. http://dx.doi.org/10.4468/2002.2.03dewoot

Forestieri G., La corporate governance negli schemi interpretativi della letteratura, Airoldi G., Forestieri G. (ed.), Corporate governance. Analisi e prospettive per il caso italiano, Etas libri, Milano, 1998.

Golinelli G. M., Vagnani G., Corporate Governance as a Viable System: the Role of Intra- and InterSystemic Relationships, Symphonya. Emerging Issues in Management (symphonya.unimib.it), n. 2, 2002.

http://dx.doi.org/10.4468/2002.2.07golinelli.vagnani

Lévi-Strauss C., Mito e significato, Net, Milano, 2002.

OECD, Les principes directeurs de l'OCDE à l'intention des entreprises multinationales, OECD publication service, France, 2000. 


\section{Notes}

${ }^{1}$ Forestieri G., , La corporate governance negli schemi interpretativi della letteratura, p. 3-4, Airoldi G., Forestieri G., (ed.), Corporate governance. Analisi e prospettive per il caso italiano, Etas libri, Milan, 1998.

2 These principles are meant, in particular, for companies that deal with capital markets. However, in the degree to which they are applicable, they can also provide a valid guide for companies operating with private capital or for public companies.

${ }^{3}$ The adaptability of the principles makes them a vital element, considering that ownership profile models in member countries are often very different from one another. While in the U.S., large publicly owned companies with numerous shareholders dominate the economic scene, in other economically advanced countries ownership is not scattered, but concentrated. This leads to different implications in relation to control mechanisms if we think, in particular, of countries in which largely concentrated ownership is flanked by the lack of any market regulation typical in the U.S. and U.K., such as pension funds, for example.

${ }^{4}$ de Woot P., The Challenges of Economic Globalisation: Business, Competition and Society, Symphonya. Emerging Issues in Management (symphonya.unimib.it), n. 2, 2002.

${ }^{5}$ Brondoni S.M., Ouverture de 'Market-Space Management', Symphonya. Emerging Issues in Management (symphonya.unimib.it), n. 1, 2002.

${ }^{6}$ Brondoni S.M., Ouverture de 'Market-Space Management', Symphonya. Emerging Issues in Management (symphonya.unimib.it), n. 1, 2002.

${ }^{7}$ It should be noted, for example, that after seven years of production in Hungary, IBM eliminated 3,700 jobs in a hard disk factory and decided to transfer all its production to China. See Hungary at risk of delocalisation, Il Sole 24 Ore, 29 November 2002.

${ }^{8}$ On the same subject, Claude Lévi-Strauss had much to say, specifying how 'the risk of our times is probably one which we could define as hyper-communication, that is, the trend to knowing exactly what is happening in every other part of the world. For a culture to really be itself and produce something, it and its members must be convinced of their originality and even, to a certain extent, of their superiority to others. It is only under conditions of hypo-communication that a culture produces something. Today we run the risk of becoming mere consumers, capable of absorbing anything from any part of the world, but lacking any originality' See Lévi-Strauss C., (2002), Myth and Meaning, Net, Milan ,p. 34.

${ }^{9}$ de Woot P., The Challenges of Economic Globalisation: Business, Competition and Society, Symphonya. Emerging Issues in Management (symphonya.unimib.it), n. 2, 2002.

${ }^{10}$ Brondoni S.M., Ouverture de 'Market-Space Management', Symphonya. Emerging Issues in Management (symphonya.unimib.it), n. 1, 2002.

${ }^{11}$ It is obvious that this is a general comment identifying a prevalent trait without any attempt to distinguish precisely between different situations. In particular, reference is made to the situation in the EU where member countries have witnessed the erosion of sovereignty, due to both a voluntary transfer of powers to community institutions (for example, on the subject of monetary policy) and as a consequence of the limits imposed by the global market.

12 Borja J., Castells M., La città globale. Sviluppo e contraddizioni delle metropoli nel terzo millennio, De Agostini, Novara, 2002.

13 de Woot P., The Challenges of Economic Globalisation: Business, Competition and Society, Symphonya. Emerging Issues in Management (symphonya.unimib.it), n. 2, 2002.

${ }^{14}$ de Woot P., The Challenges of Economic Globalisation: Business, Competition and Society, Symphonya. Emerging Issues in Management (symphonya.unimib.it), n. 2, 2002. 
15 de Woot P., The Challenges of Economic Globalisation: Business, Competition and Society, Symphonya. Emerging Issues in Management (symphonya.unimib.it), n. 2, 2002.

${ }^{16}$ The term 'global city' is intended to refer not so much and not only to large urban agglomerations. To speak of global cities means associating variable demographics with the presence of the highest functions of global management, production and administration, centres of political power, control of the media and the symbolic ability to create and spread dominant messages. See Borja J., Castells M, La città globale. Sviluppo e contraddizioni delle metropoli nel terzo millennio, De Agostini, Novara, 2002, p. 35-36.

${ }^{17}$ Brondoni S.M., Ouverture de 'Market-Space Management', Symphonya. Emerging Issues in Management (symphonya.unimib.it), n. 1, 2002.

${ }^{18}$ The European Commission (in its document 'Memorandum from the Commission in relation to corporate social responsibility: a contribution by business to sustainable development', page 7) explains how 'liberalisation processes in trade and the financial markets should be combined with the gradual implementation of an effective system of global governance that would also include the social and environmental dimensions'.

${ }^{19}$ De Montbrial Th., Le monde au tournant du siècle, Ramsès 2000, Paris, Dunod, 2000, p. 16-17.

${ }^{20}$ De Schoutheete Ph., Exposé fait au Colloqui Yalta 2000, Europe in the 21st Century, May 8 , 2000.

${ }^{21}$ de Woot P., The Challenges of Economic Globalisation: Business, Competition and Society, Symphonya. Emerging Issues in Management (symphonya.unimib.it), n. 2, 2002.

${ }^{22}$ Brotchie J., Cities in Competition: Productive and Sustainable Cities for the Twenty-First Century, Longman, Sydney, 1995.

${ }^{23}$ The three-party declarations of the ILO on international corporations and social policy go in the same direction regarding freedom of association, the abolition of forced labour, the elimination of discrimination and child labour - (1997/2000) as do the main directives of the OECD to multinational corporations (2000).

${ }^{24}$ Annan K., The global Compact. Corporate Leadership in the World Economy', Symphonya. Emerging Issues in Management (symphonya.unimib.it), n. 2, 2002, p.14.

${ }^{25}$ Up to now, projects have been carried out in the broadest spheres, such as: investments, microcredit, international labour agreements, the reduction in carbon dioxide emissions, HIV/AIDS, literacy and primary education in the local community.

${ }^{26}$ Airoldi G. - Brunetti G. - Coda V., Economia aziendale, Il Mulino, Bologna, 1994. p. 97-98.

${ }^{27}$ See Airoldi G. - Brunetti G. - Coda V., cit., p. 99 - 100.

${ }^{28}$ European Commission, Green Paper: promoting a European framework for corporate social responsibility, Brussels, 2001, p.7.

${ }^{29}$ European Commission, Green Paper: promoting a European framework for corporate social responsibility, Brussels, 2001, p. 3 . 